\title{
Censorship: The Cornerstone of Catholic Ireland
}

\author{
Anthony Keating
}

I'll tie my lips together with a string

And count their misers law a little thing;

And leave to God those who His gifts refuse

Who blind the poets and strike dumb the muse.

-An tAthair Padraigin Haicead ${ }^{1}$

This article will explore the religio-political dynamic that drove the deepening of censorship in the Irish Free State, with a particular focus upon the literary-journalistic censorship heralded in by the 1929 Censorship of Publications Act. Censorship, it will be argued, was introduced by an insecure state at the insistence of the Irish Catholic Church, ${ }^{2}$ hereafter referred to as "the church," an institution that the Free State depended on for its very survival. The church, for its part, viewed the Free State and its people as a uniquely positioned vehicle to fulfill God's mission, a mission that the church believed was under attack from foreign influences.

Additionally, Irish Catholicism will be shown to have been deeply conservative and authoritarian with an overstated pessimism regarding the people of Ireland's ability to withstand foreign vice without the application of rigid clerical discipline-a feature born of Irish

ANTHONY KEATING (BA, City of London Polytechnic; MSc, University of Oxford; MA, Edge Hill University; PhD, Dublin City University; PG Dip, University of Leeds) is senior lecturer in social sciences at Edge Hill University in United Kingdom, Lancashire. His articles have appeared in Studies, Irish Studies Review, History Ireland, Radharc: A Journal of Irish Studies, New Hibernia Review, Curum, Crimsoc: Journal of Social Criminology, and Decies. Special interests include censorship and Irish radical journals, sexual crimes/institutional abuse, and journalism in the free state.

1. Extract from a poem on censorship by the Gaelic poet and priest An tAthair Padraigin Haicead. Translated by Robin Flower. The Bell 5, no. 2 (1942): letters page.

2. The Irish Catholic Church, for the purpose of this article, refers to its hierarchy, priests, members of religious orders, and lay members active in Catholic organizations that engaged in social action and political lobbying, such as the Vigilance Association of Ireland.

Journal of Church and State vol. 57 no. 2, pages 289-309; doi:10.1093/jcs/cst097 Advance Access publication November 21, 2013

(C) The Author 2013. Published by Oxford University Press on behalf of the J. M. Dawson Institute of Church-State Studies. All rights reserved. For permissions, please e-mail: journals.permissions@oup.com 
Catholicism's particular theological underpinning, which led to the Irish people being viewed as "children" in need of "parental" protection and guidance by both church and Nationalist ideologues. ${ }^{3}$

Furthermore, the debates, inside and outside of the Free State legislature, regarding the passage of the censorship bill into law will be explored to illustrate the contested terrain of Irish democracy and identity. Censorship, it will be argued, ultimately contributed to the undermining of the Irish people's trust in both church and state authority because the cultural and religious protectionism it sought to impose fostered stagnation and corruption. The social control that censorship was designed to propagate was eventually overtaken by the very thing it sought to hold back, modernity, with its everexpanding and uncontrollable ability to communicate a plurality of views, lifestyles, and religious and political philosophies, which, in turn, led to the development of social and economic aspersions that were out of step with the world view offered by Ireland's cultural and economic isolation. These conditions were viewed by ideologues as necessary to protect its people from the outside world and the realities of life within its own borders.

This artcile will explore the issues thematically, beginning with an exploration of the wider social and political landscape that gave birth to the 1929 Censorship of Publications Act.

\section{The Social and Political Context of Censorship in the Free State}

The Irish Free State ${ }^{4}$ came into being in 1922 after a protracted guerrilla war against Britain, the colonial power, a war that was quickly followed by a bitter civil war ${ }^{5}$ between former comrades who opposed or accepted the terms of partial independence agreed with the British. A battle for the hearts and minds of the Irish people ensued in which the church was to play a decisive role in legitimizing the new state and its fledgling democracy. The church and Ireland's governing political

3. W. J. McCormack, Dublin 1916: The French Connection (Dublin: Gill \& Macmillan, 2012).

4. The Irish Free State (Irish: Saorstát Éireann; December 6, 1922-December 29, 1937) was the state established in 1922 as a Dominion of the British Empire under the Anglo-Irish Treaty of 1921 after the War of Independence, January 1919 - July 1921.

5. The Irish Civil War, June 28, 1922 - May 24, 1923, followed the Irish War of Independence and accompanied the establishment of the Irish Free State. The conflict was waged between two opposing groups of Irish nationalists-namely, the forces of the "Provisional Government" that supported the Treaty and the Republican opposition, which saw it as a betrayal of the Irish Republic that had been declared during the War of Independence. The Civil War was won by the Free State forces and left Irish society divided and embittered for generations to come. 
and administrative elite, hereafter referred to as "the state," both conceptualized the Free State as a spiritual and national rebirth of a dynamic Christian tradition that was said to have existed in the early medieval period before the English ${ }^{6}$ occupation of the country, typified as the land of "saints and scholars," a beacon of purity in a world otherwise sullied by $\sin ^{7}$

However, Ireland had been occupied for centuries by the English, and sections of its population were perceived by Catholic ideologues as having been "polluted" by "foreign vices"8 that were persisting in Ireland despite British withdrawal, "vice" driven by the engine of modernity in the form of the cinema, ${ }^{9}$ the novel, ${ }^{10}$ and the sensationalist press. ${ }^{11}$ The church saw its primary role as restoring Ireland to its former virtue through the spiritual re-education of its people and by stemming the flow of "vice" to its shores. Both church and state feared dangerous forces, within and without the state, could ultimately lead to its collapse, ${ }^{12}$ an eventuality inconceivable in the minds of the religio-nationalist elites who set about building the conditions and national characteristics that would withstand these threats. The church viewed the control of "pollutants" through the imposition of further censorship as an important part of this strategy. To this end, within the first decade of the state's existence, a draconian cinematic, literary, and press censorship was established.

\section{The Church as Powerbroker}

The power and authority of the church in the Irish Free State is difficult to overstate. ${ }^{13}$ The church provided the state with domestic legitimacy and was, in the main, willingly ceded power by the Free State government over educational and social policy by an executive

6. The English occupation of Ireland began in 1169 under King Henry II.

7. Anthony Keating, "Setting the Agenda for the Press: The 1929 Case against the Waterford Standard," New Hibernia Review 16, no. 2 (2012): 17-32.

8. Mark Finnane, "The Carrigan Committee of 1930-31 and the "Moral Condition of the Saorstát,"' Irish Historical Studies 32, no. 128 (November 2001): 519-36.

9. Kevin Rockett, Irish Film Censorship: A Cultural Journal from Silent Cinema to Internet Pornography (Dublin: Four Courts Press, 2004).

10. Julia Carlson, Banned in Ireland:Censorship \& the Irish Writer(Athens: University of Georgia Press, 1990).

11. Keating, "Setting the Agenda."

12. Bill Kissane notes that in April of 1930 the Department of Justice identified fifteen revolutionary organizations in the Free State and "concluded that each week seemed to give birth to new ones." See Bill Kissane, "Defending Democracy? The Legislative Response to Political Extremism in the Irish Free State, 1922 1939," Irish Historical Studies 34, no. 134 (November 2004): 156- 74.

13. Brian R. Calfano, Elizabeth A. Oldmixon, and Jane Suttter, "Assessing Clergy Attitudes: Ideology and Institutional Superiors," Journal of Church and State 56, no. 4 (2014): 670-90. 
largely, although not exclusively, consisting of loyal and faithful Catholics-a position that the church used to propagate the faith and bolster its own position rather than to combat inequality or reform Irish society. Indeed the church's educational policy played a role in reinforcing existing social hierarchies that were congruent with and sympathetic to the maintenance of its own authority and power. ${ }^{14}$ Notwithstanding the church's motivation in providing education and social services, it provided services that touched positively on the lives of the Irish people, thereby reinforcing the centrality of the church in the nation's life and the message it conveyed from the pulpit and from the wide range of Catholic publications that enjoyed healthy circulation figures. ${ }^{15}$

The church and its agencies further used its power and influence by ensuring that censorship, in all its forms, was brought into law. Having successfully won censorship of the cinema, ${ }^{16}$ those who favored the extension of literary and press censorship busied themselves with the more challenging task of ensuring its passage into law.

The rationale for extending censorship was presented, ostensibly, as a benign act with "Mother Ireland" and the welfare of its people at its heart, ensuring the importation of immorality, particularly sexual immorality, was not allowed to "pollute" the Free State. There is little doubt that this "benign" motivation drove many who supported the legislation, but it also offered a powerful tool in the maintenance and deepening of the hegemony of the church. Censorship, along with the church's control over education, bolstered a "collective orthodoxy... which permeated civil society and the interest groups within it" ${ }^{17}$ and afforded the church a key role in the political socialization of the emerging state, thus ensuring that the church played a powerful role in the shaping of state policy ${ }^{18}$ without the rather messy and inconvenient necessity of running for office, a feature of Irish political life that the Irish Times ${ }^{19}$ would later

14. Tony Fahey, "The Catholic Church and Social Policy," in Values, Catholic Social Thought and Public Policy, ed. Bridget Reynolds \& Sean Healy (Dublin: CORI Justice, 2007).

15. Anthony Keating, "Secrets and Lies: An Exploration of the Role of Identity, Culture and Communication in the Policy Process Relating to the Provision of Protection and Care for Vulnerable Children in the Irish Free State and Republic 1923 - 1974" (PhD diss., Dublin City University, 2002).

16. The Censorship of Films Act 1923.

17. Tom Inglis, Moral Monopoly: The Rise and Fall of the Catholic Church in Modern Ireland (Dublin: UCD Press, 1998).

18. J. H. Whyte, Church and State in Modern Ireland 1923-1979 (Dublin: Gill \& Macmillan, 1980).

19. The Irish Times is an Irish daily broadsheet newspaper launched on March 29, 1859. Formerly seen as representing the voice of the Protestant community, The Irish Times is considered to be Ireland's newspaper of record. 
personify, in the shape of the archbishop of Dublin, John Charles McQuaid, as "the grey eminence behind the Government."20

Generally scholarly exploration of the 1929 Censorship of Publications Act has focused upon its impact on creative writing and the banning of the advertising of contraception-both important aspects-but the prime focus of this legislation, the reporting of sexual scandal and crime, has received virtually no coverage, although, in fact, it carried the most severe penalties under the act $^{21}$ and its influence was to have a lasting impact on Irish journalistic freedom until the 1980s. ${ }^{22}$

An exploration of the censorship bill's passage through Dáil Éireann ${ }^{23}$ and the journalistic, or rather the lack of journalistic, opposition to it is illustrative of the power of what Claire McLoone-Richards has termed "Catholic pathology" in the Free State, a feature she identifies as a root cause of the extent and longevity of the abuse of the nation's looked after children, ${ }^{24}$ a group who needed to be made invisible ${ }^{25}$ because they were seen as tainted ${ }^{26}$ and whose existence challenged prevailing religio-nationalist trope of what constituted a truly Irish identity. ${ }^{27}$ This "pathology" was transmitted, in no small part, through the facilitation of censorship applied with a near inquisitorial zeal, with those who opposed the prevailing orthodoxy being vilified and punished as alien wrongdoers whose very existence was corrosive to the moral fiber of Catholic Ireland. ${ }^{28}$

Irish Catholicism is often typified to as "Jansenistic,"29 a term that, although disputed in relation to Irish Catholicism in its wider

20. Irish Times, December 1, 1950.

21. Anthony Keating, "The Case against the Waterford Standard," New Hibernia Review, 16, no. 2 (Summer 2012): 17-32.

22. Keiren Woodman, Media Control in Ireland 1923-1983 (Carbondale: Southern Illinois University Press, 1985).

23. This is the name of the Irish parliament.

24. Claire McLoone-Richards, "Say Nothing! How Pathology within Catholicism Created and Sustained the Institutional Abuse of Children in 20th Century Ireland," Child Abuse Review 21 (2012): 394-404.

25. Eoin O'Sullivan and Ian O'Donnell, Coercive Confinement in Ireland: Patients, Prisoners and Penitents (Manchester: Manchester University Press, 2012).

26. Harry Ferguson, "Abused and Looked After Children as 'Moral Dirt': Child Abuse and Institutional Care in Historical Perspective," Journal of Social Policy 36, no. 1 (2007): $123-39$.

27. James Smith, "Remembering Ireland's Architecture of Containment: Telling Stories in The Butcher Boy and States of Fear," Eire-Ireland: Journal of Irish Studies 3/4 (Fall/Winter 2001): 111-30; Keating, "Sexual Crime."

28. Keating, "Secrets and Lies."

29. Jansenism was a Christian theological movement that emphasized original $\sin$, human depravity, the necessity of divine grace, and predestination. See 
doctrinal content, ${ }^{30}$ is a label that commentators agree reflects "a disproportionate preoccupation with the mortality of carnal sin, combined with a general distrust of the visible world." ${ }^{31}$ The Jansinistic character of Irish Catholicism ensured that the church had no faith in the population's ability to withstand the "poison gas of foreign ideas" 32 without the active discipline of the church controlling every aspect of their lives.

The church was well organized, wealthy, and able to claim a constituency of 98 percent of the population. ${ }^{33}$ An overwhelmingly Catholic population lead by a largely Catholic government, members of which, as Garvin has observed, were educated and mentored by "priests of the Catholic Church" and whose world view was that of Irish Catholicism and whose default position was to seek guidance from Catholic ethics and theology. ${ }^{34}$ This, when combined with the real politics of an insecure state, unsure of its internal constituency, dependent on the church for the glue that held the state together, ${ }^{35}$ and combined with national uncertainty regarding recently withdrawn Britain's intentions, provided a powerful dynamic towards the state's acceptance of the church's will in regard to social legislation.

\section{The Committee on Evil Literature}

In 1925, Minister for Justice Kevin O’Higgins came under increasing pressure from the Catholic pressure group the Vigilance Association of Ireland, the Christian Brothers, and Catholic newspapers such as the Standard, ${ }^{36}$ to suppress the availability in the Free State of what these groups called "evil literature," a description that left no doubt in regard to the church's belief in the ability of such literature to morally corrode the people of the Free State.

Film censorship legislation had been introduced in $1923,{ }^{37}$ having found its genesis in the concerns that the subject matter and

Terrance Brown, Ireland: A Social and Cultural History, 1922 to the Present (Ithaca: Cornell University Press, 1985).

30. John Jordan," Irish Catholicism," The Crane Bag 7, no. 2 (1983): 106-16.

31. Ibid., 113.

32. Irish Monthly 53 (1925): 350.

33. Whyte, Church and State.

34. Tom Garvin, Nationalist Revolutionaries in Ireland (Oxford: Clarendon Press, 1987), 57.

35. Keating, "Secrets and Lies."

36. The Standard was an Irish weekly Roman Catholic newspaper founded in May 1928 in Dublin. It changed its name to the Catholic Standard in July 1963 and ceased publication in 1978 .

37. The Censorship of Films Act, 1923, one of the first pieces of significant legislation to be passed by the Irish Free State was an act "to provide for the official censoring of cinematographic pictures and for other matters connected therewith." It 
images contained in Hollywood films could corrupt the Irish people's morals, in particular those of its youth. Speaking during the debate of the 1923 Censorship of Films Act, ${ }^{38}$ Deputy Magennis declared: "Purity of mind and sanity of outlook upon life were long ago regarded as characteristic of our people. The loose views and the vile lowering of values that belong to other races and other peoples were being forced upon our people through the popularity of the cinematograph." ${ }^{39}$ This type of xenophobic pronouncement found a constituency in post-revolutionary Ireland, an Ireland that, although physically and culturally isolated from the European mainland, had developed aspects of the ideology of race and nation totalitarian ideologies on the rise across Europe. Megennis's views and others like them won the day with little opposition.

However, when it came to literary and journalistic censorship, O'Higgins felt that existing legislation was adequate and that there was no popular support for any extension of censorship. On November 3,1925 , in a written reply to a parliamentary question, O'Higgins asserted:

Under the existing law there are ample powers to deal with the sale and distribution of obsceneliterature. . . . As I understand the Deputy, however, his question relates to books and papers which may not come within the legal meaning of the word "obscene," but which may be considered hurtful to morals when read by certain classes of the community. I think he uses the word "indecent" in a very wide sense-giving it much the same meaning as "undesirable," a word which he also makes use of in his question. If I am correct in this assumption I am afraid that there are serious difficulties in the way of the State interfering to enforce a censorship such as the Deputy requests. In the first instance, it would be difficult to prescribe the standard of desirability or undesirability. This would appear a matter more for public opinion than for an official or officials appointed by the State... . On the whole, I am not yet satisfied that the State can usefully interfere to decide what the public may or may not read with propriety. ${ }^{40}$

Some commentators have argued that the state willingly embraced censorship and other restrictions relating to dance halls, ${ }^{41}$ education

established the Office of the Official Censor of Films and a Censorship of Films Appeal Board. It was amended by the Censorship of Films (Amendment) Act, in connection with advertisements for films. It was amended by the Censorship of Films (Amendment) Act, 1930 to extend the legislation to "vocal or other sounds" accompanying pictures.

38. A member of Ireland's lower House of Parliament.

39. Dáil debates 3, no. 12 (May 12, 1923).

40. Dáil debates, 13, no. 1 (November 3, 1925).

41. Barbara O'Connor, "Sexing the Nation: Discourses of the Dance Hall in Ireland in the 1930s,” Journal of Gender Studies 14, no. 2 (2005): 89-105. 
policy, ${ }^{42}$ and divorce ${ }^{43}$ because it was a way to "differentiate itself from their colonial masters." ${ }^{4}$ This is an overstatement. The state, although sometimes sympathetic to policy, was not always as keen as portrayed, O'Higgins's reluctance being a case in point. The movements that drove the dance hall legislation and literary censorship were outside of government but were a constituency that the government could not ignore, given the power and moral authority they wielded as agents of the Catholic Church; therefore the government felt compelled to introduce the legislation, rather than viewing it as an essential area of public policy.

However, after sustained lobbying and a meeting with a group of Catholic bishops in 1926, O'Higgins relented and established the Committee on Evil Literature (CEL). ${ }^{45}$ The CEL's report would provide the blueprint for the 1929 Censorship of Publications Act.

The CEL's first meeting was in February of 1926, and the CEL reported in December of the same year. Robert Donovan, professor of English Literature at University College Dublin, chaired the committee, which was charged with the task of considering and reporting on "whether it is necessary or advisable in the interest of public morality to extend the existing powers of the State to prohibit or restrict the sale and circulation of printed matter." 46

The CEL's report recommended that the current laws relating to censorship needed amending because they were ineffective in deterring "evil publications." The committee advocated that a model similar to that brought into legislation in England ${ }^{47}$ should be adopted, but, importantly, they laid greater emphasis on controls of press reporting than English legislation. The committee suggested that Irish legislation should extend the scope of English legislation " to apply the principles of that Act also to journalistic reports and writings other than reports of proceedings in the courts." ${ }^{48}$ The committee was concerned that, although the English legislation forbade the press from publishing certain medical or other details outlined in court, there was nothing in English legislation to stop the papers undertaking their own research and publishing those details outside of court proceedings.

42. See Sean Farrell, The Politics of Irish Education, $1920^{42} 1965$ (Dublin: Institute of Irish Studies, 1995).

43. See Michele Dillon, Debating Divorce: Moral Conflict in Ireland (Lexington: University Press of Kentucky, 1993).

44. Calfano et al., "Assessing Clergy Attitudes."

45. John Horgan, Irish Media, A Critical History since 1922 (London: Routledge, 2001), 12.

46. Report of the Committee of Enquiry on Evil Literature (1926).

47. The Obscene Publications Act 1857 dealt with obscenity. For the first time, it made the sale of obscene material a statutory offense, giving the courts power to seize and destroy offending material.

48. Report of the Committee of Enquiry into Evil Literature (1926). 
The issue of British newspapers printing details of crime and in particular, sexual crime, was highlighted in the evidence received by the committee $^{49}$ and was of central concern to those who advocated the introduction of legislation in regard to the issue. The reporting of crime and of sexual crime in British newspapers was seen as corrupting Irish morality. British newspapers were widely read in Ireland despite the church's regular condemnation of their content. The CEL received detailed information regarding the circulation of British newspapers in Ireland. ${ }^{50}$ A CEL member, Professor Thrift, asserted later:

\begin{abstract}
The evidence that was brought forward showed and proved to us a perfectly astounding circulation of newspapers, that almost everyone would agree were harmful-newspapers which simply set themselves out to describe crime, particularly sexual crime, with every disgusting detail; newspapers which serve no useful purpose, without any literary merit. . . . The Committee came to the conclusion unanimously that if such circulation of these newspapers could be prevented, by far and away the greatest evil done in this country would be put an end to. ${ }^{51}$
\end{abstract}

However, "evil" in an Irish context came to encapsulate anything that the church felt to be immoral or could potentially lead to immoral thoughts or acts. This included the promotion or advertising of birth control, advice in regard to the prevention and treatment of sexual transmitted diseases or sexual dysfunction, even moderately risqué stories, nudity or partial nudity, and even the advertising of products that removed underarm hair. In essence, it simply codified into law those things that were the focus of zealous Catholic activists who, on occasions, acted in a vigilante type manner in their pursuance to suppress these "evils" before the passage of the law, criminal acts they openly boasted about without any fear of arrest or conviction..$^{52}$

The committee recommended that the decision to censor a publication should be taken by a board of nine to twelve persons with a permanent secretariat. They said that these nine should be made up from the "religious, educational and literary or artistic interests of the Saorstat." 53

However, all members of the committee did not hold this view. The Reverend James Dempsey railed against the inclusion of artists on the

49. Ibid.

50. Keating, "Secrets and Lies."

51. Dáil debate, October 26, 1928.

52. John Horgan, "Saving Us from Ourselves: Contraception, Censorship and the 'Evil Literature' Controversy of 1926," Irish Communications Review 5, no. 63 (1995): 61-67; Keating, "Secrets and Lies."

53. The Irish for 'Free State,' Dáil debate, November 26, 1928. 
proposed Censorship Board. He argued: "On no account should artists be allowed on the Censorship Board. We know what they do in the name of art." He further asserted in his memo, "Texts of the classics for schools should be rigorously Bowdlerized." 54 "Bowdlerized" refers to the process of sanitizing those texts seen as having historical literary worth that dealt with issues or used language seen as too risqué for the contemporary puritanical, educational tastes. Thomas and Harriet Bowdler had published a book called The Family Shakespeare in 1807, from which had been removed "everything that can raise a blush on the cheek of modesty." 55 This view was also supported by W. B. Joyce, the leader of the delegation of the Dublin Branch of the Irish National Teachers Organisation ${ }^{56}$ in his evidence to the committee. ${ }^{57}$

The committee sent invitations to various groups to give evidence. These included invitations to Catholic and Protestant organizations and to the Chief Rabbi. However, of the non-Catholic organizations, only the Dublin Christian Citizenship Council, which was based at Christchurch Cathedral, took up the committee's invitation.

An examination of the archives of the committee and the evidence of the popularity of the English newspapers does not support the view that there was a massive groundswell of support for this measure, but rather that it was driven by a small group of Catholic activists. Despite this, the CEL asserted that there was widespread popular support for censorship. How the committee reached this conclusion, when even a leading censorship campaigner, the Jesuit R. S. Devane, had admitted to them that he had "always found it difficult to maintain public interest in the matter [public morality]," cannot be known.

Irrespective of the size of the constituency for change, the supporters of censorship viewed the extension of censorship as a moral crusade for the sake of "holy Ireland," the preservation of its church, and the souls of its people. The Christian Brothers in their submission asserted:

Until this riddance takes place, there is no chance of building up a better or holier Ireland. At present the spiritualised Irishman is quickly passing away and all of the brute that is in him is being fed almost to the point of moral leprosy, to be followed by the tempest of fire from heaven. ${ }^{59}$

54. National Archives of Ireland (NAI). Department of Justice (J) /7/3/1.

55. Martin Hoyles and Phil Evans, The Politics OfChildhood (London: Journeyman, 1989), 29.

56. The trade union for Ireland's primary (elementary) school teachers.

57. NAI. J. April 21, 1926.

58. Horgan, "Saving Us from Ourselves."

59. NAI .J. $7 / 2 / 7$. 
The view of the role of newspapers in the introduction of "moral leprosy" into the Irish social and political society was graphically illustrated in the evidence of a Vigilance Association of Ireland witness, Father McInerney, who cited Captain Harry Harrison, writing in Irish Truth on June' 6, 1925:

The lewd newspaper is a far greater danger than the public-house; and the sins and crimes that it tends to foster are of a far deeper dye, and cause more fatal social havoc, than common drunkenness. We would like to see our police as busy about bad publications as about bad public-houses. The victims of the one may be numbered by the thousand; the potential victims of the other by the hundred thousands. The poisoned minds are many times more numerous than the congested livers. ${ }^{60}$

The only religious voice of concern relating to the dangers of extending censorship was raised by a Church of Ireland clergyman, H. B. Kennedy ${ }^{61}$ spokesperson for the Dublin Christian Citizenship Council. He asserted:

The State, in any action beyond its present powers which it may contemplate for the protection of its citizens from the effect of immoral printed matter, should have due regard to the necessity in a free country of preserving the freedom of the press. He went on in his evidence to suggest that education and access to wholesome literature was the best course of prevention. ${ }^{62}$

\section{The Passage of the Bill}

After the publication of the Report of the Committee of Enquiry on Evil Literature, legislation was drawn up to introduce a censorship bill. The debate regarding this bill in the Dáil is illustrative of the tensions borne of the intellectual and religious divide in the Free State.

During the Dáil debate in early 1929, Deputies Tierney and Law suggested an amendment to the original bill, which they felt was too strict. The bill had proposed that immorality alone, in any section of a publication, would be sufficient to have it banned. The deputies proposed that this be amended to any individual books that "wholly or in general character were indecent or obscene or which advocated unnatural prevention of conception or abortion."

Professor Tierney felt the amendments were necessary because

He was anxious as anyone to keep down the sale of obscene books and other publications, but he wanted to avoid doing injustice to individuals, or to the community. It might result in attempting a kind of anti-Irish propaganda, which might do more harm in the long run.

60. Unnumbered archive document held in the Censorship Board, Dublin: 3.

61. Dean of Christchurch Cathedral.

62. Unnumbered archive document held at the Censorship Board Dublin: 1. 
This point proved prophetic, providing evidence for decades to come for those who viewed Ireland as a "priest ridden" Roman fiefdom. ${ }^{63}$ The deputies points were accepted by Minister for Justice Fitzgerald-Kenney, who agreed to modify the bill. ${ }^{64}$ The amendments to the bill seemed to have troubled the Catholic hierarchy and those who shared their worldview. By February 1929, the newspapers were carrying articles reporting sermons by Catholic bishops in which they expressed their concerns for the progress of the bill. For example, the bishop of Ossory wrote in a pastoral letter:

We trust that the Censorship of Publications Bill before Dáil Éireann will not be weakened in its progress through the Oireachtas and that it will be enacted in such a way as to face an effectual barrier to the diffusion of literature injurious to the march of our people. ${ }^{65}$

The zeal of some Catholic clerics appears to have had an impact on members of the legislature. The Irish Times reported that a Labour deputy, Mr. Anthony, claimed that the influence of clerical pronouncements made many deputies afraid to say what they thought about the censorship bill. ${ }^{66}$ Professor Tierney articulated the weight of the religious pressure visited on deputies who voiced concern over certain aspects of the bill. He complained that the government proposals for registering complaints proposed by the bill would involve him in complaining "to some of the bodies that had branded him as a 'non-Catholic' for his attitude to the Bill." In the Senate, ${ }^{67}$ Sir John Keane feared that such was the feeling that "anyone who opposed the Bill would be ostracised from public life." 68 Indeed the editor of the Catholic Bulletin referred to those who didn't follow the party line on censorship as "those low creatures, vulgarians, wastrels, materialists, mere Irish scum."69

Opposition to the bill, with one or two exceptions, came from the minority Protestant community. The construct that failure to support censorship in exactly the form proposed by the Catholic hierarchy was in some way a betrayal of Ireland itself and, worse, tacit support for the recolonization of Ireland by England was increasingly peddled by the Catholic press in this period and must have proved a potent silencer of debate. In an unsigned article entitled "Far and

63. For an example, see Paul Blanshard, The Irish and Catholic Power (Boston: Beacon Press, 1953).

64. Irish Times, February 28, 1929.

65. Irish Times, February 11, 1929.

66. Irish Times, February 22, 1929.

67. The Irish Upper House of Parliament; Irish Times, February 22, 1929.

68. Irish Times, April 12, 1929.

69. Catholic Bulletin, March 1927, 233. 
Near" in the Catholic Bulletin, the author posed the question, "What Irishman ever foresaw or imagined an Ireland so debased and despicable as to be undistinguished from England in the matter of its newspapers and periodical literature?" Then later in the same article, the author asserts, "The mind of England has been trained to criticize and think for itself; that of Ireland to believe and accept what it is taught."70

Despite attempts to silence the voice of opposition, some individuals dared to challenge these orthodoxies. Senator O'Farrell in a Senate debate in 1929 speaking of some Catholic publications asserted:

They deceive the ordinary, average, ignorant reader into believing that they are orthodox publications approved by the authority of the church, and that consequently that they should have considerable moral weight. Sectarian bitterness and animosity are favored and encouraged by these papers. They preach and practice a code that is as far removed from Christian religion as barbarism is from civilization. ${ }^{71}$

The main battle lines for this debatewere to be drawn on the issue of the composition of the Censorship Board and the method devised for referral. The government proposed that a single individual from a recognized organization would be able to refer a publication to the board. However, several deputies recognized that this would give insufficient protection at the referral stage.

Sir John Keane also opposed the bill in the Senate. He claimed that it was an attempt by politicians to impose "mental hygiene." He claimed that the mind was the last place that politicians were unable to control and that the bill was an attempt to enable them to do so. ${ }^{72}$

The pressure to conform to the will of the church regarding censorship and the consequences for failing to do so, referred to by the few parliamentarians who voiced their opposition, were doubtless equally clearly felt by the nation's secular press, which remained largely silent on the issues. The journalistic opposition that was voiced did not come from the leading national papers, the Irish Times and the Independent, ${ }^{73}$ but from voices on the fringe of Irish journalism, writing defiantly in the literary and cultural journal the Irish Statesman, who, like Ireland's artistic community, were more robust in their criticality. ${ }^{74}$

70. Catholic Bulletin, 2 (1928), 124.

71. Senate Debates, Vol. 12, Col. 106, April 11, 1929.

72. Irish Times, April 12, 1929.

73. The Irish Independent is a daily newspaper founded in 1905. For most of its history, the Irish Independent was seen as a nationalist, Catholic, anti-Communist, newspaper.

74. Keating, "Secrets and Lies." 


\section{The Silence of the Newspapers and the Opposition of the Irish Statesman}

Although it is reasonable to assume that the Irish secular newspaper industry had a vested interest in maintaining freedom of speech, they were curiously devoid of comment during the debate. The Irish Times seems to have limited itself to what may be veiled attempts at stimulating debate. In January 1929, for example, they published a long historical article on the Banned Book by John Williams. The article argued that banning and burning books does not necessarily suppress or eradicate the ideas held within them. The author points to the Bible as one such book. ${ }^{75}$ The paper also printed a lengthy report entitled "Censorship Dangers." This article detailed a resolution passed by a meeting, held in New York, of artists, authors, journalists, and actors born in Ireland or of Irish extraction. It reads as follows:

Whereas a Bill has been introduced into the parliament of the Irish Free State to place serious restrictions on the liberty of the press and on the right to publish freely one's opinions... this meeting resolves that we deplore the introduction of the Censorship Bill as a step backward towards autocracy and tyranny, institutions the Irish People long fought to overthrow because of their destructive and alien character. ${ }^{76}$

The publication of this resolution provided an obvious opportunity for editorial comment, yet the invitation was studiously ignored. The lack of comment by the Irish Times seems particularly strange when it is remembered that just three years before, in February 1926, the Irish Times had warned that a moral censorship of the press "would merely ... feed the national vice of self-complacency and would divert public attention from more urgent perils. The things that defile Ireland today come not from without, but from within," 77 a quotation that with hindsight was prophetic. However, during the debate on the introduction of censorship legislation, the Irish Times had no comment of its own on the matter.

The silence of Irish newspapers on the issue of censorship can be explained by two factors. First, as has been demonstrated, the English newspapers had far larger circulations in Ireland than the indigenous papers, and the indigenous press had more or less supported the CEL. Censorship was primarily viewed as an attack on the English press that, if successful in limiting the market for the English press in the Free State, would increase the sales figures of

75. Irish Times, January 26, 1929.

76. Irish Times, March 23, 1929.

77. Horgan, "Saving Us from Ourselves," 63. 
Irish papers. Irish newspaper proprietors may also have been buoyed by the views expressed by a leading figure in the Catholic Truth Society, R. S. Devane, who spearheaded the assault on "evil" literature and argued that "the liberty of the Irish press" would not be affected because it wasn't guilty of the vices of the foreign press. ${ }^{78}$

Second, the attitude of Irish newspapers to such legislation may have been influenced by the same factors spoken of by deputies and senators during the debate on the censorship bill. The papers may not have wanted to risk the displeasure of the hierarchy. The Irish Times in particular was attempting to shed its image of being an Orange ${ }^{79}$ paper during this period. ${ }^{80}$

The xenophobia of the Catholic publications during this period is apparent. The October 12, 1929, issue of the Standard commented that the Irish were being led on a path of restlessness of spirit that led them to seek excitement. They were clear who was to blame for this:

To foster these tendencies the secular press of protestant, nay, pagan England, backed as it is by powerful and wealthy companies are doing much.... And here in Ireland we, a small people numerically and financially compared with those across the sea, are in great danger of being influenced unconsciously perhaps, but none the less surely, by this mighty press. $^{81}$

If the secular ${ }^{82}$ Irish newspapers had found allies in the Catholic Truth Society and the right wing religious press, they may not have been inclined to bite the hand that fed them, and having supported the Catholic Truth Society, how could they now attack the resultant legislation, whatever the implications for freedom of speech.

There was, however, a notable exceptions to Irish journalism's general compliance with the church-driven censorship agenda in the shape of a weekly publication that brought far more detailed political analysis to bear on the issue-namely, the Irish Statesman. ${ }^{83}$ By tracing the debate on censorship in the Irish Statesman, it is possible to visualize a clear map of the terrain being fought over by the more

78. Submission to the Committee of Enquiry on Evil Literature. Unnumbered archive file, Censorship Board Dublin.

79. The Orange Order is a Protestant fraternal organization. Its name is a tribute to the Dutch-born Protestant King of England, Ireland, and Scotland, William of Orange, who defeated the army of Catholic James II at the Battle of the Boyne in 1690.

80. Horgan, Irish Media.

81. Standard, October 12, 1929, 3.

82. This term is used to differentiate these newspapers from Ireland's flourishing religious press of the day.

83. The Irish Statesman was a weekly journal. It ran from June 27,1919 , to June 1930, later edited by George Russell. 
liberal-minded intellectual community in the fledgling state and the more powerful church.

Although the Irish Statesman recognized the need for some level of censorship, it was convinced that current legislation was adequate for dealing with transgressors. However, it went on to focus its attack on the bill in two specific areas-namely, the inclusion in the bill of a role for recognized associations and the definition of prescribed literature under the bill as that which "tends to inculcate principles contrary to public morality or is otherwise of such a character that the sale or distribution therefore is or tends to be injurious or detrimental to or subversive to public morality." 84

The main thrust of the journal's attack on the bill was to challenge the proposed role for recognized associations. The church already had the lead role in the education of the nation's young, and the editor of the Irish Statesman was keen to ensure that it did not develop any more of the educative power that representation of recognized bodies would afford it. ${ }^{85}$ The same article also explored the misuses of the "detrimental to or subversive to public morality clause" and suggested, prophetically as it turns out, that the legislation could be used for more overt political purposes:

There are people who think sincerely that socialist literature is subversive of public morality. Would a book like Mr. Shaw's Guide to Socialism be liable to prohibition? Then again there are people who think sincerely that the literature of agnosticism is subversive of public matters. Are we to have an orthodoxy of such thought on such matters?

The editorial reinforced this by detailing what it viewed as the ludicrous lengths that individuals and representatives of the Catholic Truth Society and others would go to in order to counter what they viewed as immoral.

We have seen in Irish houses reproductions of the paintings of the Sistine Chapel by Michael Angelo, with branches and drapery painted over them. The people who did this were more moral than the Popes. We remember the attempts in Dundalk and Cork to prevent posters of a nude baby reaching for soap being used in an advertisement, and the solemn way in which bill-posters went to paint breeches on the baby!" The piece ended with a warning of a foreign press backlash and the heartfelt plea that "We do not wish our country to be made ridiculous." ${ }^{86}$

This editorial was to spark an intensive round of correspondence to the Irish Statesman and was to fill its pages with many more letters and articles expressing various opinions on the issue.

84. Censorship of Publications Bill, 1928.

85. Irish Statesman, August 25, 1928.

86. Ibid., 2-3. 
The journal highlighted concern regarding the physical force used by some groups who supported censorship and leveled a charge of complicity with this aggression against Irish newspapers for what it suspected was economic motivation. Warning sternly regarding the possibilities of such complicity:

The censors armed with revolvers who held up the limited mail outside Mullingar and burnt some thousands of papers are doubtless concerned lest principles detrimental to, or subversive of public morality should spread in Ireland. . . . We noticed that none of our dailies criticized the action of the marauders. Where they discreetly pleased? Did they feel that the removal of rivals gave them a better chance? But if there is no public opinion directed against this they may find their own papers burnt later on to give a better chance to some rival paper who's principles are approved of by the marauders.... We would like to ask if whether the men with revolvers are members of any association recognized under coming censorship. ${ }^{87}$

The Irish Statesman was clear that some of the forces that were seeking to shape the new Ireland had the potential to mold the new state into an introspective, impoverished backward nation.

However, in 1929 the Irish Statesman still believed that the Irish Free State compared favorably with many other European states in terms of freedom and tolerance. The article explored the suppression of the press by Mussolini in Fascist Italy. The journal argued that Ireland could develop a growing reputation as a bastion of freedom if

our moral fanatics do not deprive us of it by trying to prevent us reading literary masterpieces. There are quite thousands who want to be Mussolinis over literature, and if they win the first fortress they attack they will not be satisfied until we are stifled as the most autocrat-ridden nation on the continent. $^{88}$

The Irish Statesman enlisted many intellectuals in the debate in its pages, including Sean O'Faoláin ${ }^{89}$ and George Bernard Shaw. ${ }^{90}$ O'Faoláin wrote a lengthy article on the experience of censorship in the United States, which highlighted the way in which a few individuals could highjack the legislation for their own political ends. ${ }^{91}$ Bernard Shaw with his typical wit noted:

87. Irish Statesman, September 22, 1928, 45.

88. Irish Statesman, February 9, 1929.

89. Seán Proinsias O’Faoláin (February 22, 1900-April 20, 1991) was an Irish short story writer and intellectual. He founded the influential journal The Bell.

90. George Bernard Shaw (July 26, 1856 -November 2, 1950) was an Irish playwright and a cofounder of the London School of Economics.

91. Irish Statesman, October 10, 1928, 86-88. 
Under the feeble apologetic tyranny of Dublin Castle ${ }^{92}$ we Irish were forced to endure a considerable degree of compulsory freedom. The moment we got rid of that tyranny we rushed to enslave ourselves. [He went on to say that if Ireland, having broken England's grip on her,] slopes back into the Atlantic as a little grass patch in which a few million moral cowards are not allowed to call their souls their own by a handful of morbid Catholics, mad with heresyphobia, unnaturally combining with a handful of Calvinists mad with sexphobia (both being in a small and intensely disliked minority of their own co-religionists) then the world will let "these Irish" go their own way into insignificance without the smallest concern. ${ }^{93}$

The Censorship of Publications Act that eventually emerged from the Dáil in March 1929 was substantially amended in terms of its definition of the type of literature that could be banned and excluded the concept of recognized associations. The Irish Statesman seemed broadly pleased with the emerging legislation, which it felt, in part, had been diluted. ${ }^{94}$

The Irish Statesman in a conciliatory article in July 1929 asserted that the censorship bill as put to the Dáil was departure from the government's usual skillful handling of affairs. The journal chose to believe that the bill came about as the result of

an evil moment [in which Ministers] permitted themselves to be influenced by the din of a strident minority who had convinced themselves this was a golden opportunity not only to suppress pornographic stuff, but to enforce prohibitions on any and every kind of book that ran contrary to their prejudices or soared above their limited intelligence. We do not suggest that members of the government were scared by the threats of these moral bullies that anyone who dared to oppose their demands would be driven out of public life, and we have too high an opinion of their intelligence to assume that they failed to see the so-called arguments with which it was sought to justify the terrorism were balderdash of the rankest kind. The only explanation we can advance for the surrender of this impudent crusade was that our rulers came to the conclusion that it would be simpler to give the fanatics what they asked for on the very cynical ground that the mass of the Irish people did not care two straws one way or the other. ${ }^{95}$

The voice of the Irish Statesman was to be silenced in April 1930. The March 29, 1930, edition indicated that a key American funder had died and that the journal was no longer able to continue publishing. The journal, in its final edition, featured a lengthy editorial, part of which pulled no punches on what it believed to be the political

92. The seat of British administration in Ireland.

93. Irish Statesman, November 17, 1928, 206-208.

94. Irish Statesman, March 30, 1929, 64.

95. Irish Statesman, July 13, 1929, 366. 
realities of life in the Free State. The section headed "The New Secret Societies" is worth quoting at length:

That political sanity, that easing of race hatreds, are definite goods which have come to us through self government. We wish we could bring our comments on Irish happenings to an end on an altogether hopeful note. There is one change which is a distinct deterioration, and that is the character of the secret societies from which we have not freed ourselves. The secret societies of a generation ago had for object the freedom of Ireland. There was good reason, too, for their being secret. All small nationalities submerged in large empires tend to develop a subterranean political life. It is impossible to fight great battles openly, and the very character of their ideals makes open propaganda difficult. Whatever may be said against the secret society of a generation ago, their members were not self-seeking and their ideals were defensible. A new kind of secret society, or semi-secret, has come into existence, whose object seems to be a kind of religious masonry to procure business jobs and contracts for members, and they threaten, bully, or cajole barristers, solicitors and business men into membership. It is a commercialising of religion, using God to get jobs. The swift growth of this most ignoble of all Irish secret societies has come along with the publication of some semi-theological journals which have revived religious bitterness in a country where the people are naturally tolerant. The Christian virtue of charity has been so exiled from their pages that they were rebuked lately by an eminent priest. We hope that this kind of secret society, this kind of sectarian journalism are but transitory phenomena. But as it is they suggest to us an office with God in large letters over the front door and devils busy inside in complete control of the business. ${ }^{96}$

\section{Censorship Legacy}

The 1929 Censorship of Publications Act ${ }^{97}$ that eventually resulted from the campaign did far more than limit discourse on sexual morality; it skewed communication on the issues relating to the moral, economic, and political life of the nation for decades to come and became an encumbrance to Ireland's emergence into true democratic nationhood. A creature borne of authoritarian Catholic ideology, censorship was to become a political and social controller of action and thought in Ireland for decades to come. It instilled a culture of

96. Irish Statesman, April 12, 1930, 104.

97. The Censorship of Publications Act, 1929, was an act "to make provision for the prohibition of the sale and distribution of unwholesome literature and for that purpose to provide for the establishment of a censorship of books and periodical publications, and to restrict the publication of reports of certain classes of judicial proceedings and for other purposes incidental to the matters aforesaid." It established the Censorship of Publications Board. A book prohibited by the act was one that "in its general tendency indecent or obscene . . . or . . . advocates the unnatural prevention of conception or the procurement of abortion or miscarriage or the use of any method, treatment or appliance for the purpose of such prevention or such miscarriage." 
secrecy that leaves a legacy still visible in the deployment of executive secrecy by the government of contemporary Ireland. ${ }^{98}$

The 1929 Censorship of Publications Act placed the objectives of church and state above the liberty of the citizen, with profound implications for Ireland's journey into modern democratic nationhood. Church and state corruption and abuse flourished ${ }^{99}$ under the mantle of secrecy afforded by censorship. The culture it fostered would ultimately lead to a crisis of credibility for the institutions of state and the near collapse of the moral authority and influence of the church. This profound realignment of power and authority developed as the material, technological, theological, and political conditions that had maintained the postrevolutionary settlement evolved beyond the control of either church or state from the 1960s through to the 1980s. Fogerty and colleagues described this period as a time of "tension management" between "the old hegemony of Catholicism and nationalism and the emergence of liberalism and materialism." 100

The model of censorship adopted in the Free State provides a cautionary reminder of the potential for the application of the "law of unintended consequences" relating to the suppression of freedom of information and expression in pursuit of a "greater" goal.

\section{Conclusion}

The fledgling Irish Free State was a weak, insecure political entity that perceived itself as dependent, to a large degree, on the moral authority and power of the church. The church itself was authoritarian, treating the Irish people as vulnerable and naïve, in need of cosseting and protection from the influences of sin, sin they perceived as being imported into the country via the debauchery of Hollywood and the heathen excesses of the "over mighty press" of the former colonial power.

The church was adept at deploying its moral, economic, and political power to manage the content of indigenous newspapers, but the movie industry in Hollywood and the British newspapers were beyond its control. To effect a level of control, the church required

98. Jennifer M. Kavanagh, "Executive Secrecy and Access to Policy: Lessons from the Past in Irish Legal and Political History," Working Papers in History and Policy, No 7. School of History and Archives, University College Dublin (2012).

99. See Elaine Byrne, "Political Corruption in Ireland 1922-2010: A Crooked Harp?" (Manchester: Manchester University Press, 2012); Marie Keenan, Child Sexual Abuse and the Catholic Church: Gender, Power, and Organizational Culture (New York: Oxford University Press, 2012).

100. M. Fogerty, Liam Ryan, and Joseph Lee, Irish Values and Attitudes: Irish Report of the European Values System Survey (Dublin: Dominican Press, 1984). 
the state to enact legislation and set about using its considerable power base to bring censorship legislation on to statute as soon as possible. Having acted quickly on the issue of cinema censorship, the government of the Free State, a democracy, was reluctant to extend censorship further but acquiesced after sustained pressure from well-organized Catholic lobbyists and the religious hierarchy. Such was the authority and power of the church that it was able to stifle debate on an issue that was to have serious ramifications for Ireland's democracy for decades to come.

The study of the genesis, lobbying, and passage of the legislation is illustrative of the power of well-organized religious groups in a society to bring pressure to bear on elected governments to legislate in favor of their religious mission, a power that is particularly acute in weak, insecure states in which a religious organization enjoys the unquestioned support of the majority of the populace. The application of religious authority in these circumstances served to deny the emergence of a plurality of voices in parliament and the nation's press on issue of fundamental importance for Irish democracy.

The study is also illustrative of the deadening impact on a democracy of allowing an unelected religious pressure group to impose its will through legislation: in this case, a piece of legislation that did exactly the opposite that it was argued to achieve-namely, to protect vulnerable members of society. Censorship in the Irish context protected the view and interests of the Irish state and the church by presenting to domestic and international observers a view of Ireland and Irishness that both institutions wished, an agenda pursued at the cost of facing the reality of abuse in Ireland-political, economic, and sexual. 